\title{
A PHOTOGRAPHIC RECORD OF THE UPPER HEADWATER TRIBUTARIES, BASINS AND RIPARIA OF THE SNAKE RIVER
}

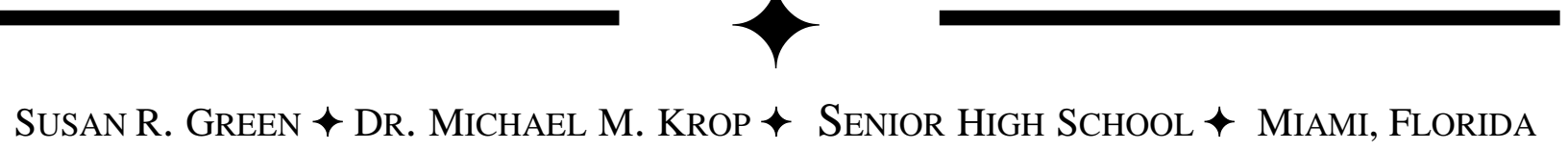

\section{$\uparrow \quad$ AbSTRACT}

Photographic surveys have been used since the early 1940's to document coastlines, fuel supplies and river courses. The US Navy, post world war II, flew over the Arctic coast to document possible locations for oil extraction. These very same photos are now being utilized to compare changes in tundra vegetation at the same locations today. John Muirs' photos of Glacier Bay are a startling testament to the melted glaciers no longer visible from the same vantage point in present times. Taking photographs to monitor change may not tell the entire story behind a change in landscape. However, photos taken over a number of years from the same vantage points, can help monitor landscape changes due to habitat fragmentation, global warming, forest fire, cattle grazing and other land management issues. Photo monitoring is inexpensive, simple and can portray change to many different groups. Of course, photos taken to reveal change must start with documenting current or normal conditions. This is sometimes called baseline monitoring. The park ranger in Glacier National Park did not realize when he took his picture of the Grinnell glacier in 1911 that his photo would become an alarming baseline photo for evidence of global warming. The purpose of this project was to document the Snake River headwater basin and its riparian zones as a document in time for future reference. The original documentation included 48 images of two main headwater areas; the Shoshone and Lewis Lake areas and the Fox ParkTwo Ocean Bear Management Areas near the Yellowstone Park border. Since the Shoshone-Lewis lakes are easily assessable and photo space here is limited, I have chosen to only use photos from the more remote areas.

\section{$\uparrow \quad$ INTRODUCTION}

In California, photo monitoring is being used to investigate and confirm changes to riparian areas do to cattle grazing. (ucdavis.org) The division of Agriculture had hopes of increasing shrub cover along stream channels. Although photos cannot reveal all the changes taking place in any area, used with the collection of other data, such as weight of organic matter in top soil, photographs can show general changes in vegetation to support additional data collected. Photos have also been used to determine the effects of dams on riparian areas of the lower Ord River in Australia. Photos taken between 1952 and 1900 at three different sites have revealed established woodland communities on low land that was previously flooded and associated species that were not present before (Pilchard, 2002).

Repeat landscape photography was also used in Virginia to assess vegetation changes in rural communities in the southern Appalachian Mountains between 1880 and 2008. In this study many of the historical photos used were taken right after the civil war when agricultural activity peaked. In current photos, forest cover actually increased by $37 \%$ due to removal of railroads and decreased agriculture. Several landscapes had changed simply by the addition of roads and bridges (Hendrick and Copenhaver, 2000). The research in this same study points out that, when possible, photographic records need to be cross referenced to historical events such as the Great Depression when land designation would often shift ownership. Cross referencing photos with other historical data can put environmental change into perspective. For example, the patterns they found in decreasing or increasing forest cover were 
compared to dendrochronological studies and local witness tree records covering the same time period.

After common images were found in the Appalachian study, the images were comparable in terms of size and pixel resolution. In this case, comparisons were made between the two time periods by quantifying the photos directly (originally conducted by Crimmins and Crimmins 2008). One set back the study found was that most of the images from the past were taken from easily accessible places like roadsides and ridge tops often from a single point. This can limit obtaining the full objectives of vegetation change over a wide geographical range and what can lead to what the author calls "special bias". They had few photographs of steeper, less assessable areas.

Another photographic study using historical photographs took place in Key West Florida. Between 1956 to 2007, photos of fish caught by sport fisherman were compared between those two years as to size and species of fish caught. The mean weight of fish declined from $19.9 \mathrm{~kg}$ to $2.3 \mathrm{~kg}$. Large groupers and large sharks ( $2 \mathrm{~m}$ in length) were replaced by smaller snapper and a $50 \%$ reduction in shark length. Historical data in this case is important for establishing baseline information for fish management implications (McClenachan 2009).

The photos in this project will include meadows, ponds, tributary creeks, continental divide features, riparian vegetation and animal trails having possible impact on the Snake River headwater areas.

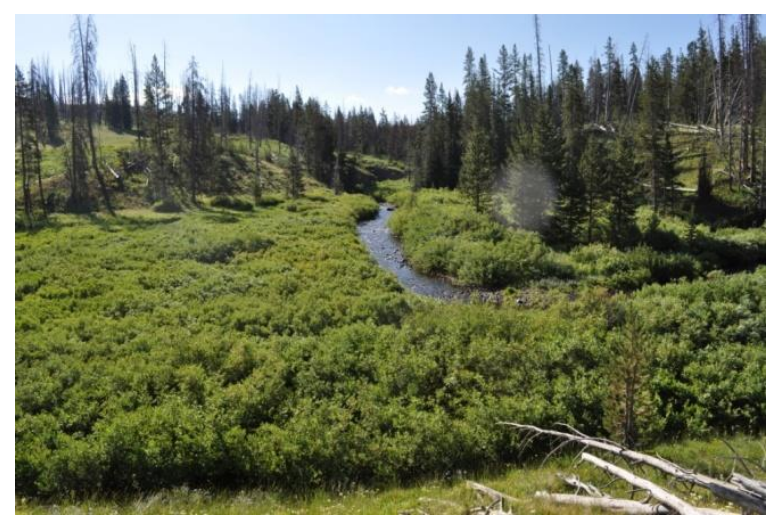

Figure 1. Snake River marsh looking ESE from Fox Park. Photo was taken about 2 miles from the end of "named river" on USGS topo maps. The river is 7 feet wide here.

\section{What is the actual source of the Snake River?}

It turns out that there has been controversy over the location of the Snake River headwaters. If you look on any USGS map and follow the Snake River with your finger to the east from Highway 89, it flows through the southern part of Yellowstone National Park. About twenty miles to the east, it takes a slight turn to the south, exits the National Park and flows through Fox Park which is in the Teton wilderness. If you continue to follow the smaller and smaller blue line labeled "Snake river", it continues south east for another two miles and then abruptly turns to the north east and ends down a small drainage. The "end" point on the map is in the Teton wilderness.

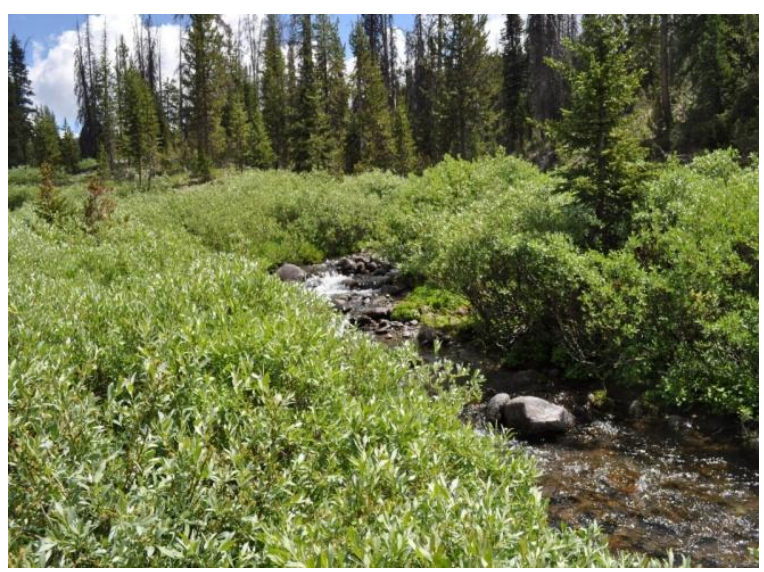

Figure 2. Looking NE and the "end" of the named Snake River on USGS maps. Two creeks flow into the Snake at this location.

John Turner, the former director of the US Fish and Wildlife Service, who spent years rafting Wyoming's rivers and traveling in the Wyoming wilderness disagrees with the USGS. The Turners believe that Fox Creek, which enters Fox Park from the south is the beginning of the Snake river and was labeled incorrectly. An early survey map also calls Fox Creek the Snake (Palmer1991). The USGS disagrees and calls the northern fork, pictured above, a larger and longer extension of the river and therefore the "source".

In 1970, Joe Shellenberger and Paul Lawrence, two backcountry enthusiasts attempted a pilgrimage to deliberately find the beginning of the Snake. Lawrence claimed that the source "was a spring bursting from a mountain side south of Yellowstone Park". They claimed they followed the river to the base of an unnamed mountain on the divide just south of Yellowstone. On their way back down they entered a smaller gorge to the south that they had bypassed on their way up. A trickle appeared to them, the first actual flowing water that they had seen up the "Snake river" ravine. They descended a bit further, stepping over rocks and 
fallen trees and then "suddenly a stream, 3 feet wide, plunged through the gorge. From a two foot slot in the rock, padded by moss, the snake River flowed from the ground".

Exactly where the Snake river begins is not critical to this project but rather the entire upper tributaries, streams and highest watercourses that enter the Snake at the higher elevations. The ponds, meadows and riparia associated with these high water courses are also important to this documentation. The Snake River "headwaters" is actually a fairly large area encompassing approximately 1,000 square miles if you include the Shoshone, Lewis and Heart Lakes drainages as well. My husband and I have tried to assess the headwaters area in the Teton wilderness for seven years. The area is approximately twenty four miles from the nearest trailhead. There are numerous stream and river crossings. The area is said to be the most remote in the lower forty-eight states. We found it necessary to access this area by horseback because of the difficulties involved. Our party camped near Fox Creek patrol cabin and hiked into the upper headwaters on foot.

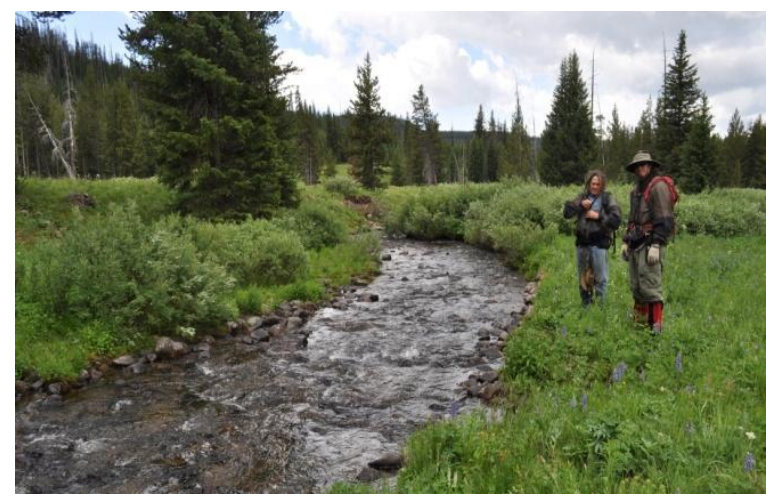

Figure 3. Snake River looking downstream due south. We "jumped across" just north of this picture.

\section{Riparian Characteristics}

To most casual observers the riparian is just where a river or stream meets the land; a shoreline from water to land. But this zone to a researcher is a much more complex ecological interface. This boundary region can be narrow and encompass gravel and a few plants or can extend several hundred yards from a water course and be considered important to the overall recharge of groundwater. Some researchers believe that the riparian even includes some of the higher elevated terracing along the banks of stream courses where tree populations' impact soil stability or nutrient loads into a water course. There is debate as to whether riparian zones are unique functioning ecosystems in themselves (Naiman et al.
2005). Since they are highly variable and exist because of the water running through them, the diversity of life in the riparian is often variable from the larger landscape.

Riparian zones are dynamic and can change seasonally, monthly or even daily. Disturbances such as a tree falling over into a stream can redistribute soils and sediment miles downstream. Climate and weather change can influence plant productivity and thus animal activity. Since the interface between a waters' course and its boundaries are so active and interchangeable, it is common for altered riparian landscapes to have profound impacts on the health of freshwater rivers and streams. It is unfortunate that human activities such as building and logging along rivers and streams has seriously degraded riparian zones and the courses they bound. There has been a significant increase in studies done on riparian zones since 1995 (Naiman et al. 2005). We have begun to recognize the ecological importance of maintaining the health of these areas. We now know that riparian zones control flooding, absorb nutrient runoff, flush out biological contaminants', reduce the impact of disease pests, minimize erosion of soils and provide diverse habitat for many organisms. There has been an increase world-wide effort to restore riparian habitat along major river courses even in highly populated and industrialized areas.

In order to photograph what may be considered important riparian landscape features, the following is a brief description of these features:

1. Stream corridors; elevated or continuous views when possible.

2. Multidimensional gradients; changes in stream patterns, banks, deposition of sediment.

3. Concentrated biodiversity; tree populations, vegetation.

4. Drainage basins; ponds and meadows associated with the riparian landscape or smaller water sheds divided by the topography of the area.

5. Fire damage

6. Water levels; of all riparian features for the specific point in time when the photo was taken.

7. Beetle damage; affected trees.

8. Wildlife: photographed when possible or written record.

9. Animal trails; through the riparia. 
10. Horse trails; for general documentation of human impact.

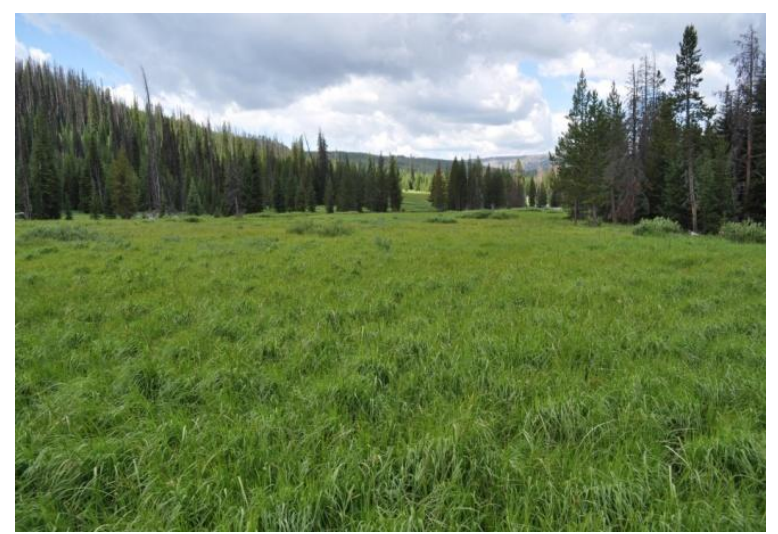

Figure 4. Healthy riparian vegetation along the upper Snake. Photo looking SSW, Snake River to far right.

\section{The Environmental Impact of humans on Backcountry trails: a Brief Summary}

A small portion of the photos presented in this project will document various sections of the backcountry trails used to access the areas photographed (Figures 1-11). These photos may also provide a record to forest managers of high trail usage areas and trail maintenance issues. The literature reviewed provides a very divided opinion of the impact of hikers, bikers and horse traffic on backcountry trails. Each interest group extends the blame of trail degradation to another group. Both bikers and hikers seem to have an equal impact on backcountry trails. Minimal impact on the physical trail and trailside vegetation was stated. However bikers seem to have more serious bear encounters since they travel more quickly and tend to surprise the bears. Because bikers move through areas more quickly, they do not necessarily look for nor see wildlife. Hikers on the other hand tend to stop and stare or even follow wildlife for a better picture (Sprung 2007). The literature regarding horse use on trails is very controversial. According to Adda Quinn from "Envirohorse", the horse is considered a "lightweight, low-impact" user of backcountry trails. Her literature states that the initial building of the trail itself causes erosion by water and other natural forces and "overshadow" the effects of horse traffic. She further quotes a study by Williams (1998) whereby "moderate horse activity may help to maintain a multiple-use trail". The studies she presents in her research state that there has been no documented evidence which supports the rumors of horses spreading exotic weeds or degrading water sources. Quinn contends that stream crossing damage (riparian) can be avoided by building bridges and by the rider encouraging the horse to urinate away from streams.

Other studies show that horses can and do have a larger impact than bicyclists or hikers. It has been stated (Woody) that horses can cause up to four times as much impact to trails as do other types of recreationists. Woody's research shows that horse traffic results in statistically significant higher sediment yields which he claims is the number one indicator of trail deterioration. Horses' hooves loosen soil particles therefore increase runoff whereas hikers continually compact and do not loosen the soil. Horse trails that wind through wet areas such as marshes, meadows and riparian landscapes can severely impact these areas. The weight of the horse sinks in the soft earth turning under vegetation and creating muddy pits that fill in with water often contaminated with horse urine and manure. When the water evaporates the soil hardens to leave deep holes and ruts that are difficult for bikers or bikers to navigate. The Rattling Creek Single Trackers mountain bike club in Lykens, Pennsylvania built a trail through the Weiser state forest there. When horse riders started to use "their" trail, they took before and after pictures before a spring horse competition. Several parts of the trail were in wet, stream bank areas. The bikers were furious with the damage done to the trails. The spokesman for the bike club called the horses, "fourlegged post hole diggers". He continued by saying that, "We did not build these hiker-biker trails to be torn up by another group that is not planning to return to repair the damage....trails cannot sustain a thousand pound animal in soft conditions". The horse competitors responded to the comments by saying that the forest was public land and they have just as much right to be there.

The photos submitted in this project (Figures 1-11) are for documentation purposes only and are not intended to promote or discourage the use of horses on back country trails. From the literature read on this subject and my own observations, it would appear that the only agreement between the various trail users is that better maintenance by the forest service and others, better trail design and the addition of bridges in wet areas would greatly prevent trail deterioration.

The Snake River headwater basin is located in two main areas. A few of the Lewis and Shoshone Lake tributaries will be recorded. The majority of the documentation however, will concentrate in the more remote areas of Fox Park Basin and Two Ocean Plateau Bear Management area. Fox Creek and Fox Park are located in Teton wilderness. Lewis and 
Shoshone lakes are located in Yellowstone National Park as well as the Two Ocean Bear Management area.

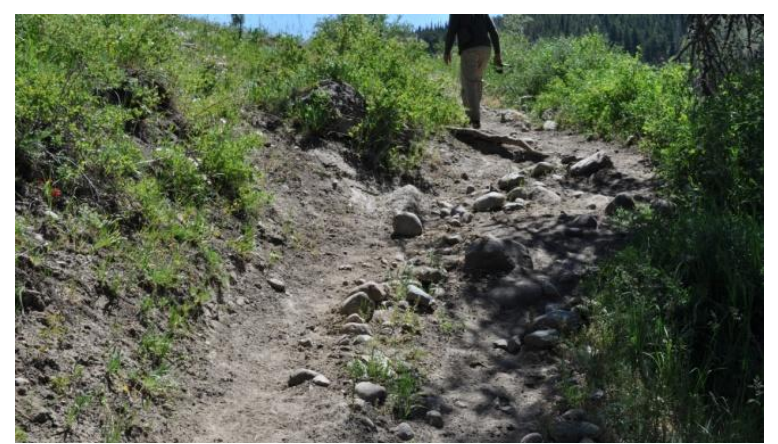

Figure 5. Buffalo River trail- showing damage from horse traffic. Trails widen, become deeper and lose topsoil near trail heads.

\section{$\uparrow \quad$ MeThODS}

Each photo taken was recorded with the corresponding latitude and longitude coordinates, elevation, compass bearing and any written noteworthy observations. Photographic period: July 8-July 25, 2010. A total of 14 days were spent in the backcountry recording the photographs for this documentation. Since the Fox Park and Two Ocean Plateau areas are the most remote, seven days were required to document these two areas. The Two Ocean Plateau Trail in Yellowstone Park does not open until July $15^{\text {th }}$. Hikers are not allowed to leave the trail in this bear habitat. It was necessary to acquire a special permit to photograph the headwater areas during the time of this trip.

\section{Equipment:}

Two cameras: Nikon D5000 with Nikon mounted GPS, Nikon Coolpix 5400, topographical maps, index cards, compass and markers.

\section{Summation:}

The main objective of this project was to photograph the headwater basins, tributaries and riparia of the upper Snake River. Remarkably, most of the photos taken were not in the serious burn areas of the Pacific, Huck and Yellowstone fires. A huge corridor running north and south between both the Huck and Mink Creek fires was the location where most of the photos were taken. There were spotty areas where burned trees could be seen but not the burn devastation seen in the Gravel Lake drainage from the Huck fire. Once the Continental divide is crossed, going north on the Big Game Ridge Cutoff trail, the burn area decreases as you descend into the Fox Creek drainage.

The meadows, riparia and forest of Fox Creek, Fox Park and the upper tributaries of the Snake River basin area were green, lush, wet and unburned. The ground in the lower areas of both Fox Park and the upper tributaries of the Snake was soggy but no standing water was seen in the willowy, open meadow and grassy areas. The riparia of the entire headwater area photographed appeared healthy.

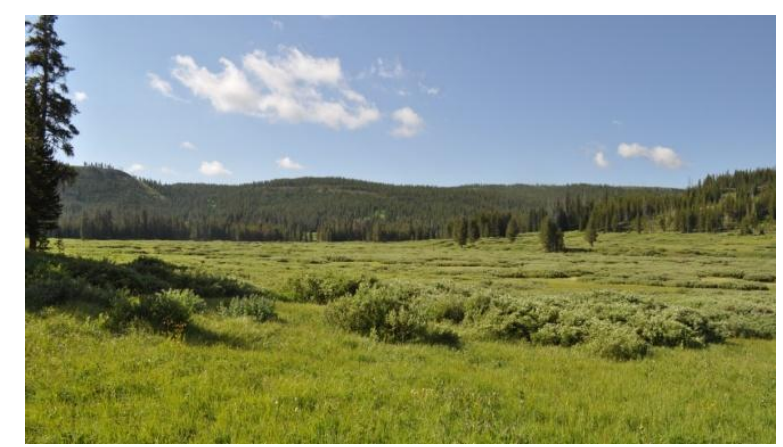

Figure 6. Snake River meanders through willow meadow east of Fox Creek patrol cabin.

Deer, elk, coyote and Sandhill cranes were seen in the upper headwater basin as well as many small green-grey marsh frogs scattering in the tall grass. Moose, deer, elk and grizzly tracks were seen on all of the game trails in the upper snake basin as well as in Fox Park and along Fox Creek. Although very few horse tracks could be seen heading northeast into the headwater basin, they appeared to have no impact on the riparia at all and could no longer be seen one mile into the upper Snake water shed. No human impact could be seen at all up to and around the west end of the balloon shaped lake and the east end of Mariposa Lake. The extensive meadows around both Balloon and Mariposa lakes were beautiful and soggy.

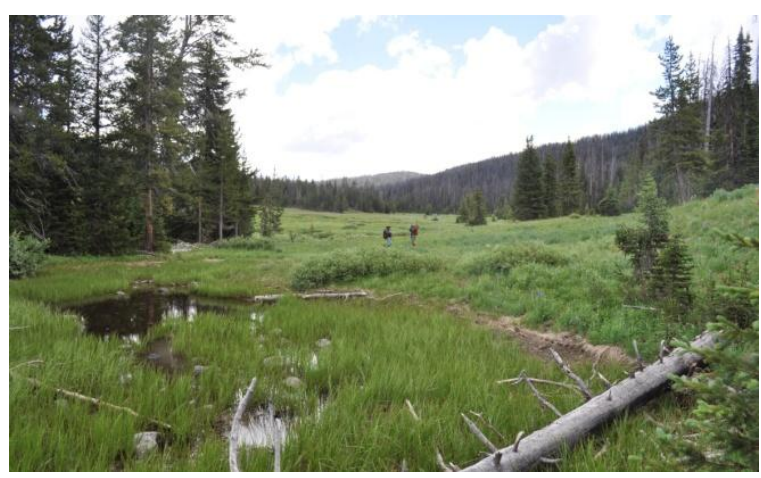

Figure 7. Snake River drainage looking NNE towards the divide in the background. Snake river in upper center of photo. 


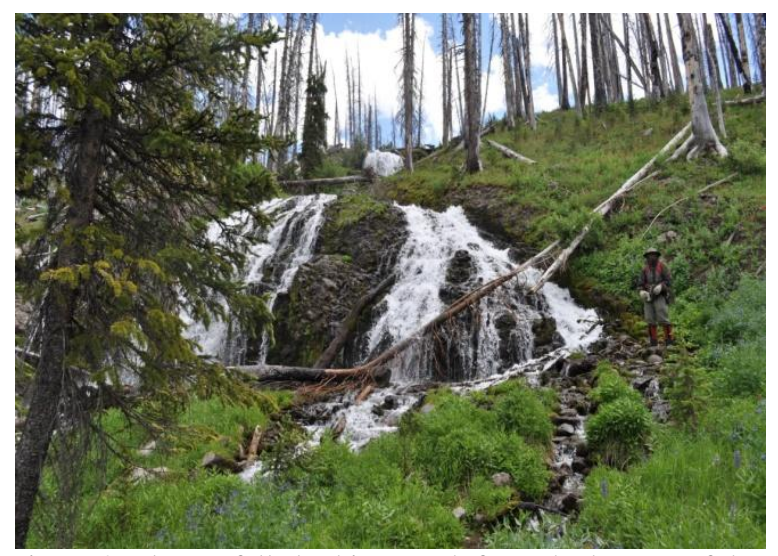

Figure 8. Plateau falls looking south from the bottom of the fourth tier.

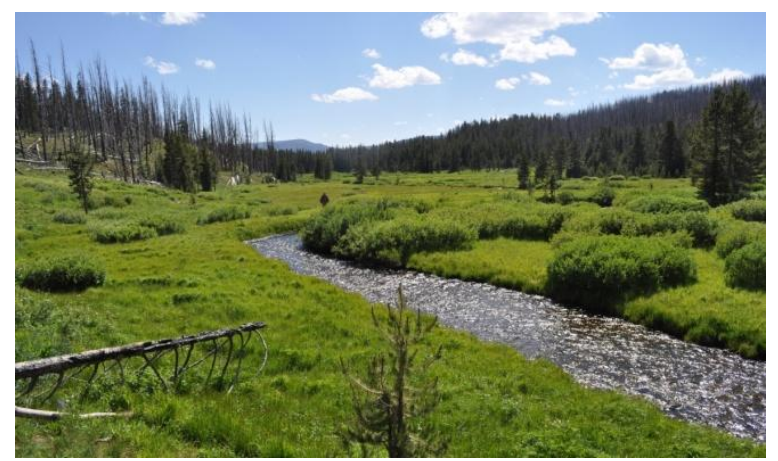

Figure 9. Plateau Creek looking downstream (west) to Two Ocean Plateau Trail.

Plateau Creek and Plateau Falls had spotty fire impact but appeared healthy, green and lush. Game trails were spotty as well with prolific wildflowers in bloom, especially Indian Paintbrush and Lupine. Descending Plateau Creek to the west, the meadows are large with tall, green grass and willow. A game trail slowly became a human trail as you approach the Two Ocean Plateau Trail which runs north and south. Fox Park was also wet and soggy but with no standing water in the large, open meadows. Willowy areas had small streams running through them.

Several Turpin Meadows trails and the Pacific Creek trails showed extensive impact by horse traffic. The first four miles of both trails had deep ruts, extensive post-holing by the horses in wet areas, multiple trails and muddy depressions in riparian and open meadows. Further in, fallen trees over trails required the horses to make large detours which impacted a larger area. Many of these trees were in riparian zones which caused the horses to descend steeper terrain causing larger patches of soil to become exposed. These conditions seem to pose not only greater impact on the habitat but also a greater risk to both horse and rider as well.
The entire Fox Park and upper Snake basin was photographed while hiking. The ground appeared to be soaked under your feet. One had a sense that many square miles of saturated ground descended right to the water table. This soaked ground would continue to drain southwest into the smallest tributaries and then into the Snake itself until winter hid its flow from view. Snow will eventually melt the following spring and soak the ground again.

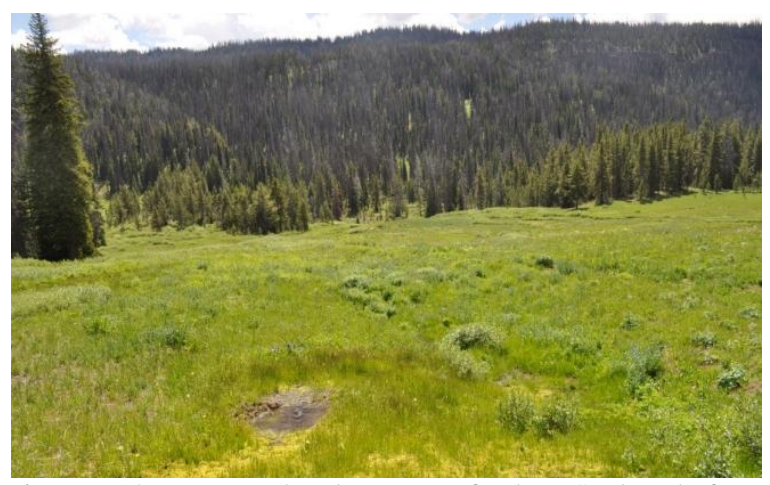

Figure 10. upper headwaters of the Snake before continental divide rise; looking ENE down into the Snake river basin; spring in foreground rises from saturated ground.

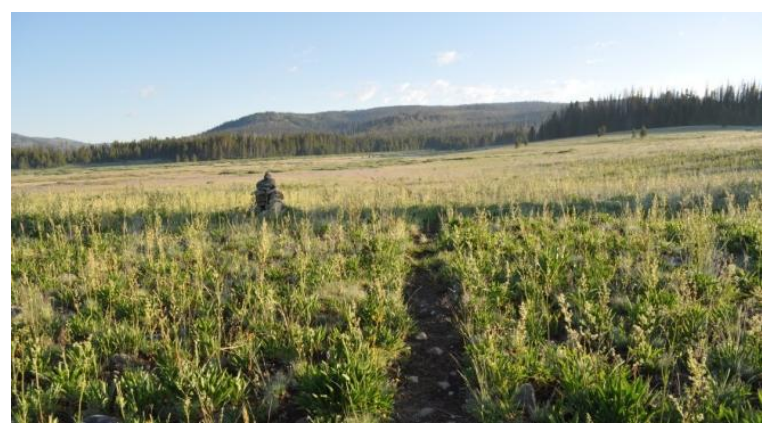

Figure 11. Fox Park looking NNW down the Continental divide Trail with trail cairn; Snake river flows through center of park.

\section{$\uparrow \quad$ ACKNOWLEDGEMENTS}

Many thanks to Hank Harlow for accepting my project plan which allowed my husband and I to satisfy our desire of many years to reach the Snake headwaters. My deep admiration and thanks to the University of Wyoming for continuing the AMK research center where I have seen and heard such wonderful work presented by scientists. I would also like to thank Matt Vandzura, Snake River District Ranger in Yellowstone, for granting me the permit to enter the Two Ocean Bear Management area. I would not have been able to pull off the horse travel without Dan Miller, an exceptional wrangler and gentleman from the Turpin Meadows ranch. My husband Terry Green helped put the logistics together for the whole 
trip. Thank you Terry for continuing to keep the adventures alive and for the best camp pancakes EVER. My thanks also to my nephew Kevin Marchese for his endless energy in hauling water and firewood and helping me with advanced power point tactics! And finally, my good friend Jose Perez for being a better horse handler than the rest of us and for helping rescue a moderately poor meal plan on my part. I forgot how much gear those panniers can actually hold!

\section{$\downarrow$ LiTERATURE CITED}

Crimmons MA, Crimmons TM. 2008. Monitoring plant phenology using digital repeat photography. Environmental Management, 41(6): 949-958.

"Current Issues", Shawnee National Forest. Trail Designation Project Draft Environmental Impact Study.

Farley W. 2007. Reins tightened on Horse Trail. The Mountain Eagle News.

Griffen RD, Stahls W, Therrell MD. 2005. Repeat photography in the ancient Cross Timbers of Oklahoma, USA. Natural areas journal 25 92): 176-182.

Hendrick L, Copenheaver C. 2008. Using Repeat Landscape Photography to Assess Vegetation changes in rural Communities of the southern Appalachian Mountains in Virginia, USA. (Mountain Research 7 Development).

Hudson WM, Marston R, Ostresh L. 1990. Wyoming Water Atlas. University of Wyoming.

Keen W. Trail Maintenance and Management. American Trails.org

Malanson G. 1993. Riparian Landscapes. Great Britain, University Press, Cambridge.

McClenachan L. 2009-05-20 Historical Photos Documenting Changing Reef Communities. Paper presented at the annual meeting of the International Marine Conservation congress, George Madison University, Fairfax, Virginia Online (PDF). 2010-05-18.
McDougald N, Clawson WJ. 1993. Natural resource management project photo plots. University of California Cooperative Extension and USDA Soil Conservation Service, Rangeland watershed Program, Fact sheet No. 24.

Mcdougald N, Frost WE, Clawson WJ. 1990. Photo points as a monitoring tool. In: Clawson WJ editor. Monitoring California's annual rangeland vegetation, University of California, division of Agriculture and Natural Resources, Publication 21468.

Naiman R, Decamps H, McClain ME. 2005. Riparia. Elsevier Academic Press, London.

Palmer T. 1991. The Snake River. Island Press, Washington DC.

Peters A, Deboodt T. Using photos to monitor riparian areas In: Riparian restoration and monitoring workshop. April 30 to May 3 1996, La Grande, Oregon.

Pilchard J. 2002. Assessing vegetation change over a century using repeat photography. Australian Journal of Botany 50(4):409-411.

Quinn A. Environmental Aspects of Horses on Trails. Americantrails.envirohorse@yahoo.com

Skovlin JM, Strickler GS, Peterson JL, Sampson AW. 2001. Interpreting Landscape Change in High Mountains of Northeast Oregon from Long Term Repeat Photography. PNWGTR-505. Portland, OR.

United States Department of Agriculture, Forest Service, Pacific Northwest Research Station.

Sprung G. 2007 Natural Resource Impacts of Mountain Biking. International Mountain biking Association.

Williams B. 1998. Horse Trails in Ecological Reserves" presented at Clemson University Horse Trails Symposium.

Zier JL, Baker WL. 2006. A Century of Vegetation Change in the San Juan mountains, Colorado; An Analysis using repeat photography. Forest Ecology and Management 228(1):251-262. 